\title{
A COMPREHENSIVE INVENTORY AND ECOLOGICAL ASSESSMENT OF ALIEN PLANT INVASION IN MIZORAM, INDIA
}

\author{
Rabishankar Sengupta and Sudhansu S. Dash* \\ Botanical Survey of India, CGO Complex, Sector-1, Salt Lake, Kolkata, India
}

Received: 21 April 2020, Revised: 10 October 2020, Accepted: 27 October 2020

\begin{abstract}
A COMPREHENSIVE INVENTORY AND ECOLOGICAL ASSESSMENT OF ALIEN PLANT INVASION IN MIZORAM, INDIA. Invasion by alien plants has a detrimental effect on the natural forest plant community, leading to the loss of native species. An inventory of alien plants facilitates in determining the potential threats to the natural plant biodiversity. This present paper evaluates the alien plants in Mizoram (an Indo-Burma hotspot region) and provides the first authentic inventory of alien plants of Mizoram along with their diversity, ecological aspects, origin, and status of invasion. Extensive field surveys were done during July 2018 to September 2019 in different protected areas of Mizoram. We adopted Random Sampling Technique using nested quadrats in a plot size of $400 \mathrm{~m}^{2}(20 \mathrm{~m} \times 20 \mathrm{~m})$, within which a quadrate size of $5 \mathrm{~m} \times 5 \mathrm{~m}$ was laid for shrubs and $1 \mathrm{~m} \times 1 \mathrm{~m}$ was laid for herbs. Plant specimens were collected, dried, poisoned with $0.1 \%$ Mercuric Chloride $\left(\mathrm{MgCl}_{2}\right)$; voucher specimens were prepared and deposited in Central National Herbarium, Botanical Survey of India (CAL) after proper identification. The results revealed the occurrence of 163 alien plant species under 135 genera belonging to 51 families in Mizoram. Maximum species were represented by family Asteraceae with 29 species followed by Leguminosae (19 species), Convolvulaceae ( 9 species), Euphorbiaceae ( 7 species) and Amaranthaceae ( 7 species). The $57.66 \%$ of the alien species reported from Mizoram were of American origin followed by $11.65 \%$ from African, 7.36\% from Mexican and 5.52\% from Australian origin. Life form analysis revealed the presence of 58.64 $\%$ herbs, $15.43 \%$ trees and $9.87 \%$ shrubs. Out of the whole alien plants recorded, 91 species were used for traditional medicines, 43 species as ornamental, 15 species were edibles, nine species used as timber and four species used as green manure. The study also recommends the ten most obnoxious species, five neoinvasive plants, which have the greatest potential threats to the native flora. The process and probable causes of invasion in the state were also discussed briefly, which may be utilized in the preparation of conservation or forest management policies.
\end{abstract}

Keywords: Alien plants, invasive, neo-invasive, biodiversity, Mizoram

INVENTARIS ASI KOMPREHENSIF DAN PENILALAN EKOLOGI INVASI JENIS-JENIS ASING DIMIZOR AM, INDIA. Invasi oleb tumbuhan asing memiliki efek yang merugikan pada komunitas tumbuhan hutan alam, yang menyebabkan bilangnya spesies asli. Inventarisasi tumbuban asing memudabkan untuk menentukan potensi ancaman terhadap keanekaragaman hayati tumbuhan alami. Tulisan ini mengevaluasi tumbuban asing di Mizoram (wilayah botspot Indo-Burma) dan merupakan inventarisasi otentik pertama tanaman asing Mizoram bersama dengan keanekaragaman, aspek ekologi, asal-usul dan status invasi mereka. Survei lapangan ekstensif dilakukan dari Juli 2018 bingga September 2019 di berbagai kawasan lindung Mizoram. Pengambilan sampel mengadopsi Teknik Pengambilan Sampel Acak menggunakan kuadrat bersarang di plot berukuran $400 \mathrm{~m}^{2}(20 \mathrm{~m} \times 20 \mathrm{~m})$, di mana ukuran kuadrat $5 \mathrm{~m} \times 5 \mathrm{~m}$ diletakean untuk semak dan $1 m \times 1$ m untuk tumbuban. Spesimen tanaman dikumpulkan, dikeringkan, diracun dengan 0,1\% Mercuric Chloride $\left(\mathrm{MgCl}_{2}\right)$; voucher spesimen disiapkan dan disimpan di Central National Herbarium, Botanical Survey of India (CAL) setelab identifikasi yang tepat. Hasil penelitian menunjukean terjadinya invasi 163 spesies tumbuban asing di bawah 135 genera milik 51 famili di Mizoram. Spesies terbesar yang teridentiflkasi adalah famili Asteraceae dengan 29 spesies diikuti oleh Leguminosae (19 spesies), Convolvulaceae (9 spesies), Euphorbiaceae (7 spesies) \& Amaranthaceae (7 spesies). 57,66\% spesies asing yang dilaporkan dari Mizoram berasal dari Amerika diikuti oleb 11,65\% dari Afrika, 7,36\% dari Meksiko \& 5,52\% dari Australia. Analisis bentuk. kebidupan menunjuk.kan keberadaan 58,64\% tumbuhan, 15,43\% pohon dan 9,87\% semak. Dari selurub tumbuban asing yang tercatat, 91 jenis dimanfaatkan untuk pengobatan tradisional, 43 jenis

*Corresponding author: ssdash2002@gmail.com 
sebagai tanaman bias, 15 jenis untuk dimakan, sembilan jenis digunakan sebagai kayu dan empat jenis digunakan sebagai pupuk bijau. Studi tersebut juga merekomendasikan sepuluh spesies paling membahayakan, lima tanaman neo-invasif, yang memiliki potensi ancaman terbesar bagi flora asli. Proses dan kemungkinan penyebab invasi di negara bagian juga dibahas secara singkat, yang dapat digunakan dalam penyusunan kebijakan konservasi atau pengelolaan butan.

Kata kunci: Tumbuhan asing, invasif, neo-invasif, keanekaragaman hayati, Mizoram

\section{INTRODUCTION}

Alien plants, introduced or spread outside their natural habitats, have affected natural biodiversity in almost every ecosystem type on earth and are one of the greatest threats to biodiversity (UN, 2014). These plants not only affect the species composition, spatial distribution of the native flora but also impact directly or indirectly on the resources, structures and functions of natural ecosystems (Downey \& Richardson, 2016). Efficient mechanism of seed dispersal, high growth rate, great adaptability to wide ranges of environmental conditions are some of the essential processes for the successful establishment of alien plants (Simberloff, Parker, \& Windle, 2005). Species that can withstand a wide range of environmental conditions show a broader physiological niche and are likely to be more invasive (Higgins \& Richardson, 2014). Almost $0.5-0.7 \%$ of global woody plant species is currently invasive outside their natural range (Rejmánek \& Richardson, 2013).

Invasive alien species can be recognized as a critical component of global environmental change because, after establishment, they randomly proliferate in all direction; mainly when the environment is conducive as in a rough and sloppy mountain terrains (Rumlerová, Vilà, Pergl, Nentwig, \& Pyšek, 2016). The recent global climate change has also catalysed the rate of introduction and spread of alien species into areas where they were previously absent, or increased their performance as compared to native species. Evidence is quite common when many invasive alien species viz. Ageratum conyzoides, Ageratina adenophora, Chromolaena odorata, Lantana camara, Mikania micrantha and
Parthenium bysterophorus have brought about havoc in terrestrial ecosystems, while Eichhornia crassipes, Pistia stratiotes in aquatic ecosystems by significantly changing the structure and composition of native vegetation (Raizada, Sharma, \& Raghubanshi, 2008).

Taxonomic identity of alien species, their origin, distribution, spread pattern, habitat and mode of introduction are the prerequisite for any management strategy against invasive species. The entire region of Northeast India including Mizoram, Khasia and Jaintia hills (K\&J hill), Lushai Hills, Manipur were under Assam province during the colonial era. Mikania micrantha was introduced during World War-II as a ground cover for tea plantations and camouflaged the airfields in this region (Shankar, Yadav, Rai, \& Tripathi, 2011). Therefore, the introduction of the alien plants in Mizoram might have followed the path K\&J hill- SilcharAizawl-Lushai hills and subsequently spread throughout the state. Report on the collection of Mikania micrantha dated back to 1956, Chromolaena odorata in 1938, Ageratina riparia in 1958 and Ageratina adenophora in 1931 from this region.

Sporadic information is available on alien species, particularly on Indian Himalayan regions. Ecological studies on invasive plants, mainly on Ageratum conyzoides, Parthenium bysterophorus and Lantana camara were reported from the north-western Himalayan region (Kohli, Batish, Singh, \& Dogra, 2006); 571 alien species enumerated from the Kashmir Himalayas (Khuroo, Reshi, Rashid, \& Dar, 2011); 190 alien species identified from Indian Himalayan region (Sekar, Manikandan, \& Srivastava, 2012); 497 alien species enumerated 
from Himachal Pradesh (Jaryan, Uniyal, Gupta, $\&$ Singh, 2013). However, accurate estimation on the spread of invasive species and its potential threats is not available from North-eastern states of India, particularly from Mizoram. A proper estimation of floristic elements or landscapes infested with invasive alien plants is the need of the hour to build appropriate strategies for conservation and management of natural flora. Keeping in mind these problems, the present study was carried out in the state of Mizoram (a) to prepare a comprehensive inventory of alien plant species in Mizoram and (b) to evaluate the invasion status of the ten most obnoxious invasive alien plant species; and to propose the five neo- invasive alien plant species, which possess potential threats to the local flora.

\section{MATERIAL AND METHOD}

\section{A. Study Site}

The state of Mizoram is one of the smallest north-eastern states of India situated in the extreme eastern part of India (Figure 1); the state is bounded by two international boundaries viz., Myanmar (Burma) on the east and Bangladesh on the west; Tripura, Assam and Manipur also share a common border with the state. The forest cover of the state is $73.68 \%$ of the state's total geographical area out of which only $6.75 \%$ is under protected area network. Summer temperature varies from $18^{\circ} \mathrm{C}$ to $29^{\circ} \mathrm{C}$ and winter temperature varies from $11^{\circ} \mathrm{C}$ to $24^{\circ} \mathrm{C}$. The average annual rainfall of the state ranges between $2160 \mathrm{~mm}$ to 3500 $\mathrm{mm}$ (FSI, 2019). For the convenience of the present work, we have selected four protected
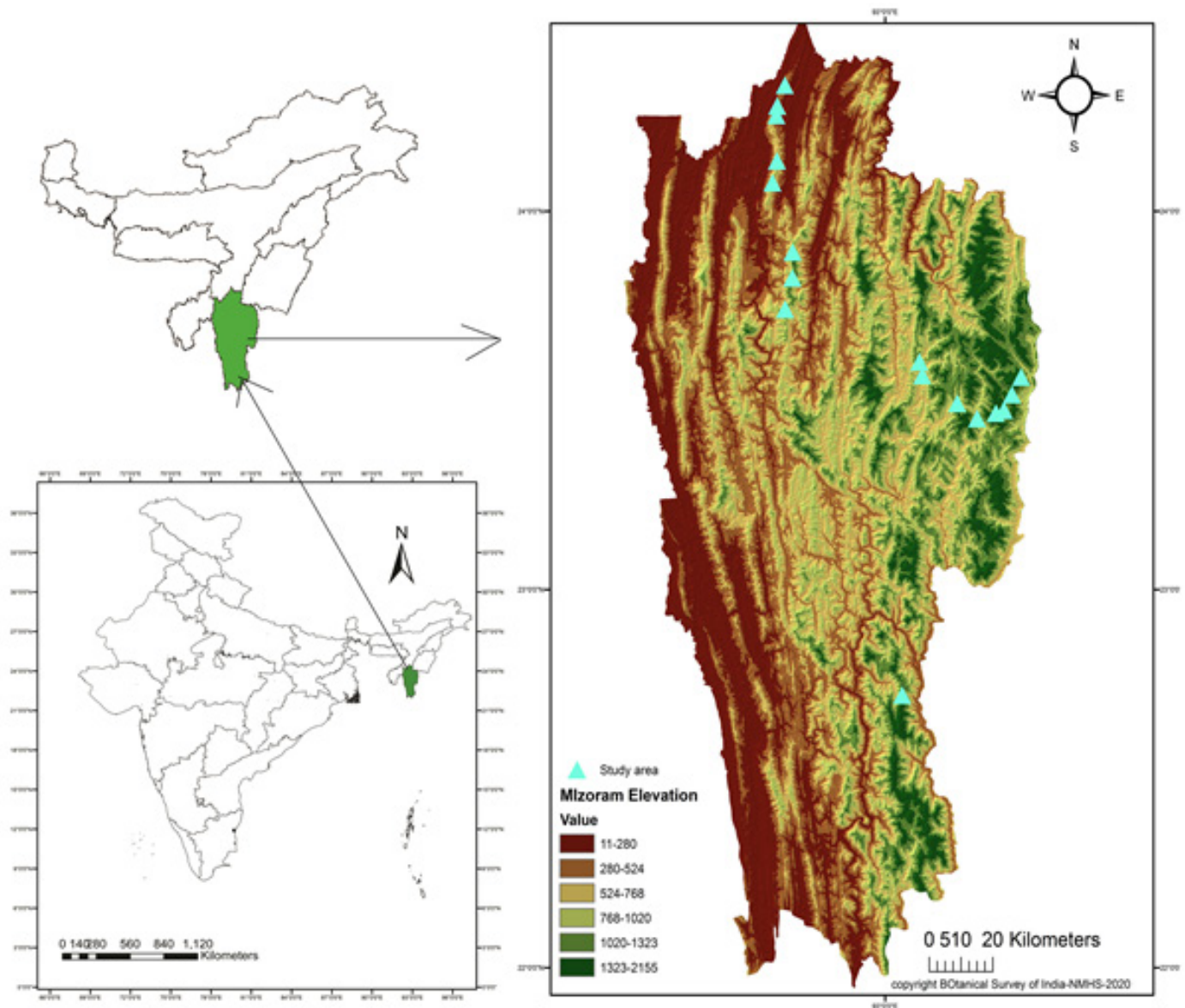

Figure 1. Map of the study site 
areas viz. Phawngpui National Park $\left(50 \mathrm{~km}^{2}\right)$, Murlen National Park $\left(100 \mathrm{~km}^{2}\right)$, Lengteng Wildlife Sanctuary $\left(60 \mathrm{~km}^{2}\right)$ and Dampa Tiger Reserve $\left(500 \mathrm{~km}^{2}\right)$. Besides non-protected areas viz. Sangau, Aizawl, Knahlan were also selected. The vegetation of the state can be broadly categorized in to tropical (up to 900 $\mathrm{m})$, subtropical $(900-1800 \mathrm{~m})$ and temperate (1800-3600 m) depending on the elevation and precipitation. All the studied plots were situated in subtropical and temperate regions of the state.

\section{B. Methods}

The present study was carried out during July 2018 to September 2019 as a part of the collaborative research project "Ecological Investigations to understand causes and consequences of invasion in Tripura \& Mizoram" under the National Mission on Himalayan Studies (NMHS). Intensive field surveys were undertaken in a planned manner in different seasons to collect the plant specimens from selected protected and unprotected areas of Mizoram. Plant samples were collected for preparation of voucher herbarium specimens. The specimens were poisoned with $0.1 \%$ Mercuric Chloride $\left(\mathrm{MgCl}_{2}\right)$, mounted on standard handmade herbarium sheets $(28 \times 42 \mathrm{~cm})$ and labelled $(14.5 \times 11$ $\mathrm{cm})$, after incorporating all the relevant field information. These were deposited in Central National Herbarium, Botanical Survey of India (CAL) after proper identification. An exhaustive inventory of alien plants of the state was prepared based on the collections from the field and also by examining the herbarium specimens from multiple herbaria (CAL, ASSAM and ARUN) of the region. Based on the mode of introduction, rate of invasion, nature of the invaded habitats and importance value index (IVI) ten most obnoxious invasive alien plants and five top neo-invasive species were grouped. For the collection of data on the mode of introduction and usefulness of alien plants, the local people were interviewed with an open-ended questionnaire.
Random sampling technique using nested quadrat method was followed for collection of phytosociological data. Plot sizes of $400 \mathrm{~m}^{2}$ were selected randomly within which quadrats of $5 \mathrm{~m} \times 5 \mathrm{~m}$ were laid for shrubs and $1 \mathrm{~m} \times 1$ $\mathrm{m}$ for herbs nested within $5 \mathrm{~m} \times 5 \mathrm{~m}$ quadrats (Misra, 1968). All the invasive species occur within each plot were counted along with their associated species. Trees were not considered in the present study because their invasion status is negligible compared to the shrub and herb invasion in the study areas. For the collection of data on the mode of introduction and usefulness of alien plants, the local people were interviewed with an open-ended questionnaire.

\section{Data Analysis}

All the phytosociological data i.e., relative densities, relative frequency, relative dominance, IVI of each species were determined using formulas mentioned by (Misra, 1968). Importance Value Index (IVI) was calculated by the addition of relative values of frequency, density and dominance (Curtis \& McIntosh, 1950).

The formulae used for the various calculations are:

$$
\begin{aligned}
& \text { Density }=\frac{\text { No. of individuals of a species }}{\text { Total No. of quadrats studied }} \\
& \text { Frequency }(\%)=\frac{\text { No. of quadrats of occurrence of a species }}{\text { Total number of quadrats studied }} \times 100 .(2) \\
& \text { Abundance }=\frac{\text { Total No. of individuals of a species }}{\text { Number of quadrats of occurrence }} \\
& \text { Relative Frequency }=\frac{\text { Frequency of a species }}{\text { Frequency of all the species }} \times 100 \ldots . .(3) \\
& \text { Relative Density }=\frac{\text { Density of a species }}{\text { Density of all the species }} \times 100 \ldots . .(5) \\
& \text { Relative Dominance }=\frac{\text { Basalarea of a species }}{\text { Basal area of all species }} \times 100 \ldots . .(6)
\end{aligned}
$$

Where: Basal area $=\pi \mathrm{r}^{2}, \pi=3.14$ and $\mathrm{r}=$ radius of the species; Importance Value Index (IVI) = Relative Frequency + Relative Density + Relative Dominance 
Importance Value Index (IVI) was calculated separately for each species of the community. A particular species, that having highest value of importance value index (IVI) is considered as most dominant in the area and the species with lowest importance value is considered as the least dominant.

The comparisons among the phytosociological data were analysed in Microsoft Excel Software (2019 version). GPS locations were investigated and the digital elevation map of the study site was prepared using ArcGIS online tools. Based on the mode of introduction, rate of invasion, nature of the invaded habitats and importance value index (IVI) ten most obnoxious alien invasive alien plants and five top neo-invasive species were determined.

\section{RESULT AND DISCUSSION}

Extensive field exploration tours undertaken in the protected and non-protected areas of Mizoram resulted in a collection of more than 1045 plant samples. During the study, 163 alien plant species were recorded from Mizoram belonging to 135 genera and 51 families (See Appendix 1, Table 1). Out of these, 147 species belongs to 122 genera and 43 families were dicotyledons; 11 species belongs to 9 genera and five families were monocotyledons. Five species of gymnosperms under four genera and three families were also recorded.
Table 2. Top ten families among the alien plants (with minimum fourspecies)

\begin{tabular}{rll}
\hline No. & Family & Species \\
\hline 1. & Asteraceae & 29 \\
2. & Leguminosae (s.l.) & 19 \\
3. & Convolvulaceae & 9 \\
4. & Euphorbiaceae & 7 \\
5. & Amaranthaceae & 7 \\
6. & Malvaceae & 6 \\
7. & Solanaceae & 7 \\
8. & Verbenaceae & 5 \\
9. & Acanthaceae & 4 \\
10. & Poaceae & 4 \\
\hline
\end{tabular}

Besides, out of the total reported plant species, 95 plant species were represented by herbs $(58.28 \%), 25$ trees $(15.33 \%), 20$ shrubs (12.26\%), 14 climbers $(8.58 \%)$, four grasses $(2.45 \%)$ and only two species of sedges $(1.27 \%)$. Maximum percentage of alien plants, i.e., $38.03 \%$ (62 taxa) occur in Mizoram were from Tropical American origin followed by 13.49\% (22 taxa) from South American, 9.81\% (16 taxa) from Tropical African, 7.3\% (12 taxa) from Mexican and 5.5\% (9 taxa) from Australian origin. The plants belonging to the different nativity was given in Figure 2.

The most dominant families with maximum species diversity shown in Table 2. Asteraceae with 29 species represented was the most dominant family followed by Leguminosae, Convolvulaceae, Euphorbiaceae,

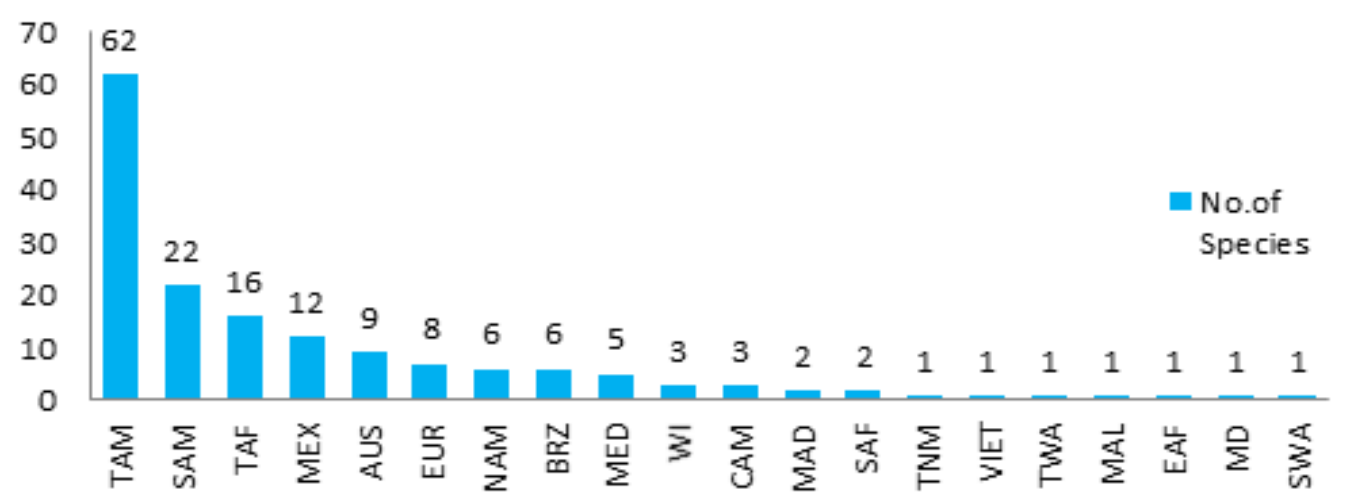

Figure 2. Nativity of the different invasive alien species found in Mizoram flora 


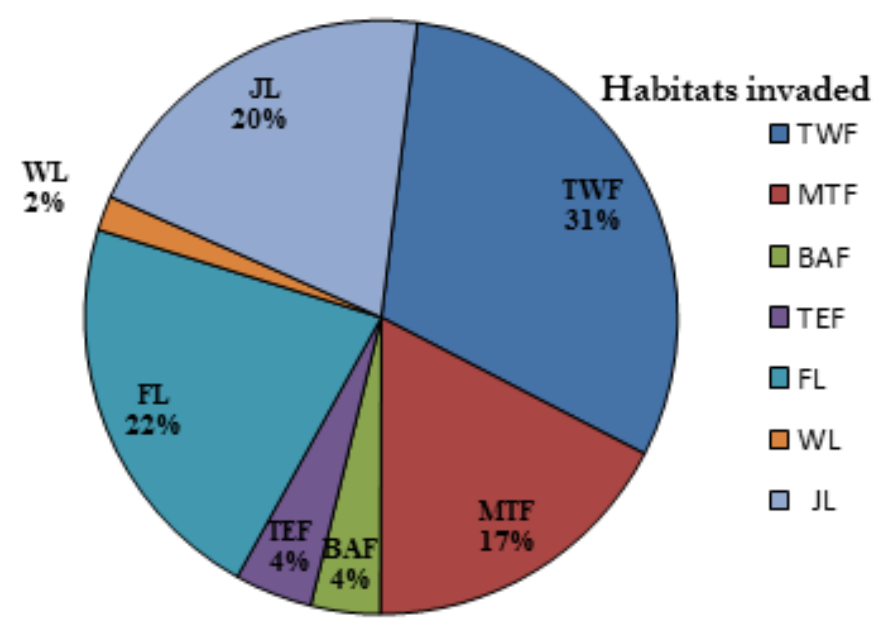

Figure 3. Habitats invaded by the invasive alien plant

Amaranthaceae, and Malvaceae. Ten most dominating families contribute $59.06 \%$ of total alien species found.

Among the most dominant families, two families viz., Asteraceae, Convolvulaceae were also reported as dominant in Indian Himalayan region (Sekar, Manikandan, \& Srivastava, 2012) as well as throughout India (Reddy, 2008). The dominance of these two families as effective invaders in natural forests may be attributed to the high production of viable seeds which usually dispersed by wind in Asteraceae, and successful vegetative reproduction in members of Convolvulaceae.

Observation on invaded habitats revealed that Tropical Wet Evergreen forest (31\%) and Montane sub-tropical forest $(17 \%)$ were most invaded forests whereas Fallow Lands (22\%) and Jhumlands (20\%) were invaded habitats outside the forest area (Figure 3). It is also found that $52.5 \%$ of alien plants were perennials and $47.5 \%$ annuals. The percentage of perennial alien plant contribution in Mizoram (52.5\%) is higher than the average contribution of Indian Himalayan region (37\%) implies that alien species are probably well established in Mizoram, or natural vegetation is more vulnerable. A moderate-higher percentage of annual alien species in the state indicates, the forest is degraded and also substantiate our findings of the gregarious spread of invasive species in mountain slopes (Figure 6). The preferred habitat of spreading of invasive species in different habitat in Mizoram is almost similar to other Indian Himalayan region (Sekar, Manikandan, \& Srivastava, 2012) as well as throughout India (Reddy, 2008). The most preferred habitats of roadsides, wetlands and fallow lands may be attributed to low competition and high disturbances in these regions.

An open-ended interview with the local villagers, forest officials and in-depth observation on the probable mode of introduction of the alien species revealed, $62.34 \%$ of the total alien species possibly introduced unintentionally while $29.62 \%$ of species were introduced for ornamental purpose and $8.02 \%$ were introduced as a food (Figure 4).

The biodiversity of a forest area controls the economy of the surrounding villages and partially fulfils their basic requirements like food, medicine, thatching material, and fodder etc. Study on the use pattern of the alien species among the local inhabitants revealed that 91 species had been used as medicinal purposes, 43 species as ornamental, 15 species as foods, nine species as fuel woods, four species as green manure and use of 6 species were not known to the locals (Figure 5). Acmella oleracea (flowers, stems), Solanum torvum (seeds) were 


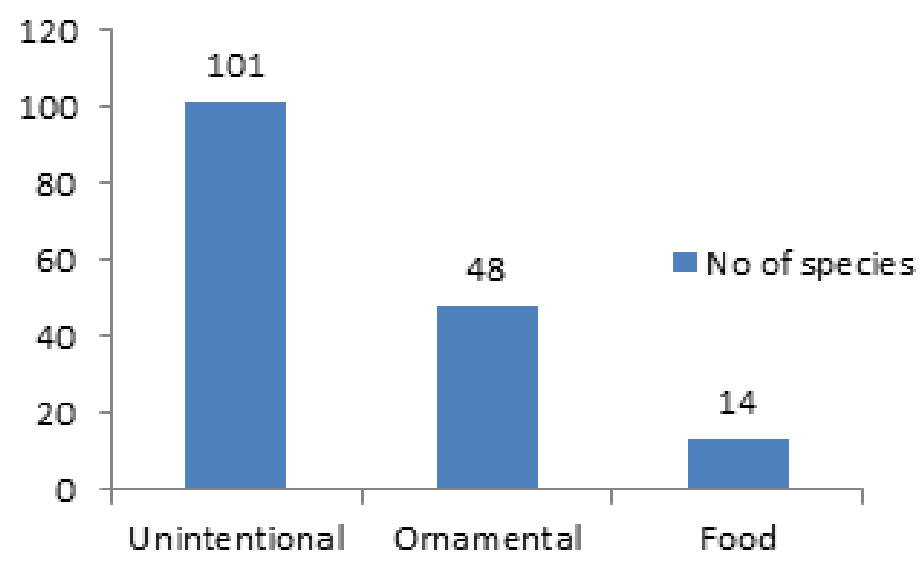

Figure 4. Mode of the introduction of the invasive alien plants in Mizoram

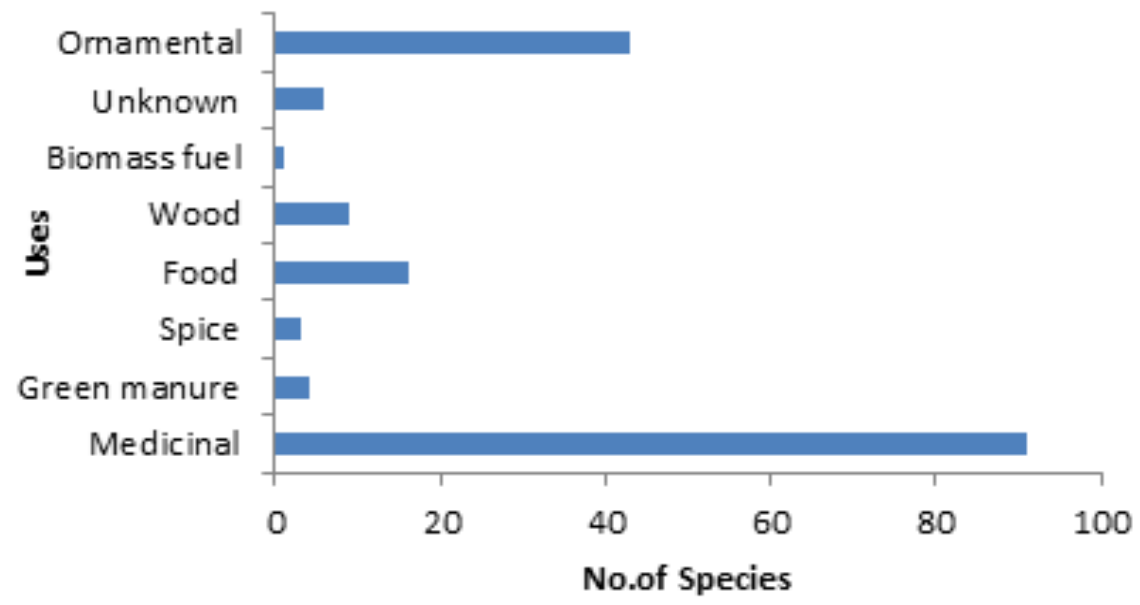

Figure 5. Uses of alien plants in the state

used for curing toothache; Bidens pilosa (leaf juice) was used for swollen glands and as eyedrops. Crushed leaf juice of Chromolaena odorata, Mikania micrantha were applied externally on cuts and wounds as antiseptic; leaves of Oxalis corniculata were eaten raw to reduce stomach ache. Leaf juice of Achyranthus aspera and Ageratum conyzoides were applied on sore-legs of domestic animals. Dried inflorescences of Ocimum americanum and dried leaves Eryngium foetidum were used as condiments in local cuisine. Tender fruit pods of Leucaena lencocephala were boiled with other vegetables for food. Argemone mexicana extract was used for adulteration purpose with mustard oil. Annona reticulata and Annona squamosa fruits were consumed widely by the locals. Leaves of Saccharum spontaneum and Typha angustifolia were used for rope making and thatching purpose. Brooms made up of dried leafless stems of Sida acuta were used for household cleaning purposes.

Based on the phytosociological data, ten most invasive alien plants in four protected areas (Phawngpui National Park, Murlen National Park, Lengteng Wildlife Sanctuary, Dampa Tiger reserve) were observed highly proliferative. In Phawngpui national park, Ageratina adenophora (IVI-62.76), Hypoestis phyllostachya (IVI-29.06), Ageratina riparia (IVI50.91) were the most dominant invasive alien species with associated native species like Lobelia pyramidalis (IVI-54.46), Lindenbergia grandiffora (IVI-52.27), Anisocbilus carnosus (IVI-37.55) and Ainsliaea latifolia (IVI-36.01) occurring between 
1400-2250 m of elevation whereas Chromolaena odorata (IVI-45.83), Mikania micrantha (IVI59.64), Imperata cylindrica (IVI-24.83) were observed dominant over native species like Strobilanthes maculata (IVI-21.20) and Impatiens stenantha (IVI-32.53) up to $1550 \mathrm{~m}$ of altitude only. In Phawngpui National Park, frequency of native species was higher compared to other three protected areas. In Murlen National Park, native plants like Ainsliaea latifolia (IVI-23.65), Oplismenus burmanii (IVI-20.04) and Strobilanthes maculata (IVI-18.09) associated with dominant invasive plants Ageratina adenophora (IVI-57.94), Ageratina riparia (IVI- 46.11), Mikania micrantha (IVI-57.10) and Lantana camara (IVI-44.48), Chromolaena odorata (IVI-37.05) were observed in 700-2149 $\mathrm{m}$ of elevation. In Lengteng Wildlife Sanctuary, between $400-1250 \mathrm{~m}$ of altitude, Impatiens stenantha (IVI-20.16), Eragrostis curvula (IVI-20.74), Oplismenus burmanii (IVI-23.96), Strobilanthes maculata (IVI-17.75) and Osbeckia chinensis (IVI-28.88) were dominant associated native species with invasive alien plants like Chromolaena odorata (IVI-35.76), Lantana camara (IVI-39.3). Whereas in between 1250-2141 m of elevation, the spread of Ageratina adenophora (IVI-55.31), Ageratina riparia (IVI-77.23), Mikania micrantha (IVI-50.42) were most abundant suppressing associated native species like Lobelia pyramidalis (IVI- 11.11), Lindenbergia grandiflora (IVI-13.33), Anisochilus carnosus (IVI22.96) and Ainsliaea latifolia (IVI- 8.89). In Dampa Tiger Reserve, between 800-1100 m of elevation, Mikania micrantha (IVI-45.39), Lantana camara (IVI-47.34), Ageratum boustonianum (IVI-45.33), Bidens pilosa (IVI-39.15), Ageratum conyzoides (IVI-66.86) were observed as most abundant invasive species showing dominance over native species like Osbeckia chinensis (IVI31.89), Elatostema sessile (IVI-31.90), Impatiens stenantha (IVI-22.44) (Table 3). It has also been observed that Ageratina adenophora, Ageratina riparia, Chromolaena odorata spreading throughout Mizoram between $700 \mathrm{~m}$ to 2200 $\mathrm{m}$ of elevation.

The gregarious spread of these invasive species greatly hinders regeneration of secondary forests and also crops probably due to their allelopathic effect and growth inhibitors. A similar result was also reported from agricultural lands of eastern Himalayas (Shankar, Yadav, Rai, \& Tripathi, 2011). The other significant impacts of alien plants on native biodiversity are usually changed soil nutrient composition and species richness. The main reasons for the great invasion in these areas may be attributed to the construction of roads, laying of water pipelines and electric poles through forest areas and forest clearance for agricultural lands. A similar observation was also observed in Siwalik low land forests of western Himalaya where $50-64 \%$ density of native flora were lost due to invasion of Ageratum conyzoides (Batish, Kaur, Singh, \& Kohli, 2009). Reduction in productivity and increase of maintenance cost was caused by fast-spreading of invasive alien plants in agriculture ecosystems (Dogra, Kohli, Sood, \& Dobhal, 2009).

Besides the ten most obnoxious invasive species, other new potential invasive plants observed in Phawngpui national park and Lengteng wildlife sanctuary were Tithonia diversifolia (IVI-33.41, 26.24), Ipomoea hederifolia (IVI-35.80, 36.50), Ipomoea cairica (IVI-29.10, 25.18), Crassocephalum crepidioides (IVI-45.53, 11.51), Galinsoga parviflora (IVI-21.12, 20.30). We have observed only one potential new invasive species Ipomoea hederifolia (IVI-37.53) in Murlen national park and two potential new invasive species Ipomoea cairica (IVI-46.58), Crassocephalum crepidioides (IVI-22.62) in Dampa tiger reserve in Mizoram. These new invasive species were firstly invading into the natural vegetation regions and posed a significant threat to it (Table 4).

From the present study, it can be concluded that Ageratinaadenophora, Ageratinariparia, Mikania micrantha, Lantana camara, Ageratum houstonianum, Chromolaena odorata, Hypoestis phyllostachya, Bidens pilosa, Imperata cylindrica, Ageratum conyzoides are the most harmful alien plants responsible for a high-volume invasion in forest lands, roadsides and fallow lands which causing noticeable damage to the flora of Mizoram. Besides five most neo-invasive species, namely Tithonia diversifolia, Ipomoea hederifolia, Ipomoea 

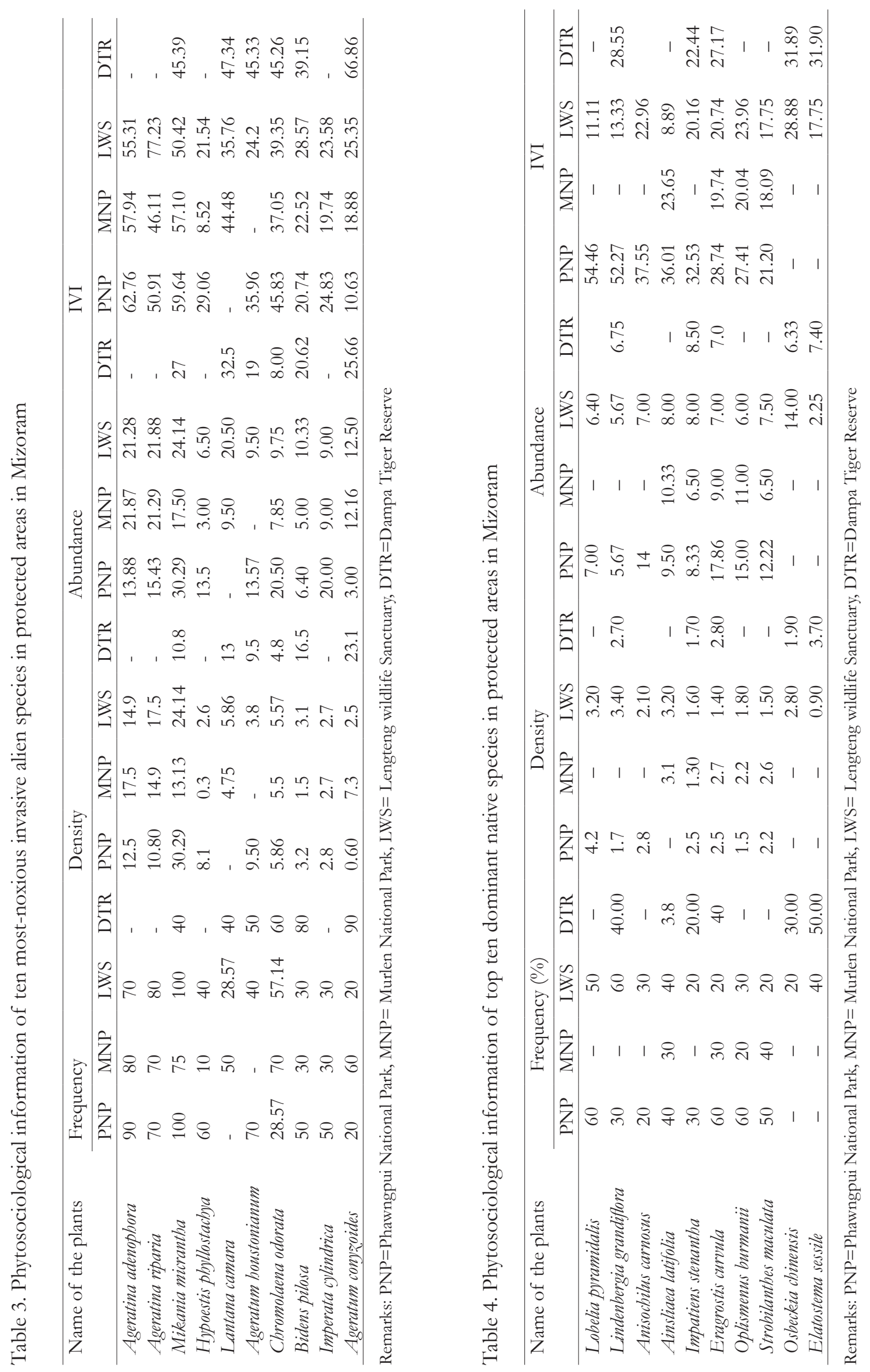


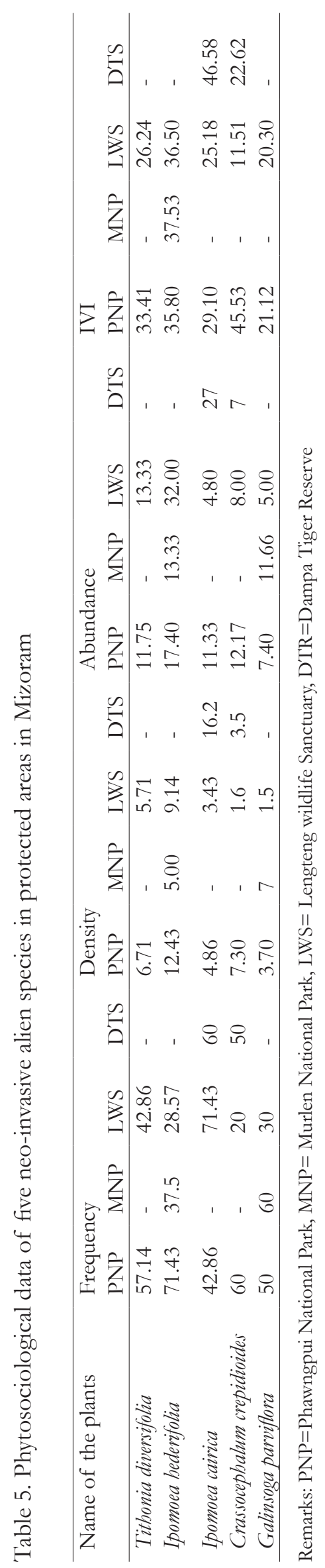



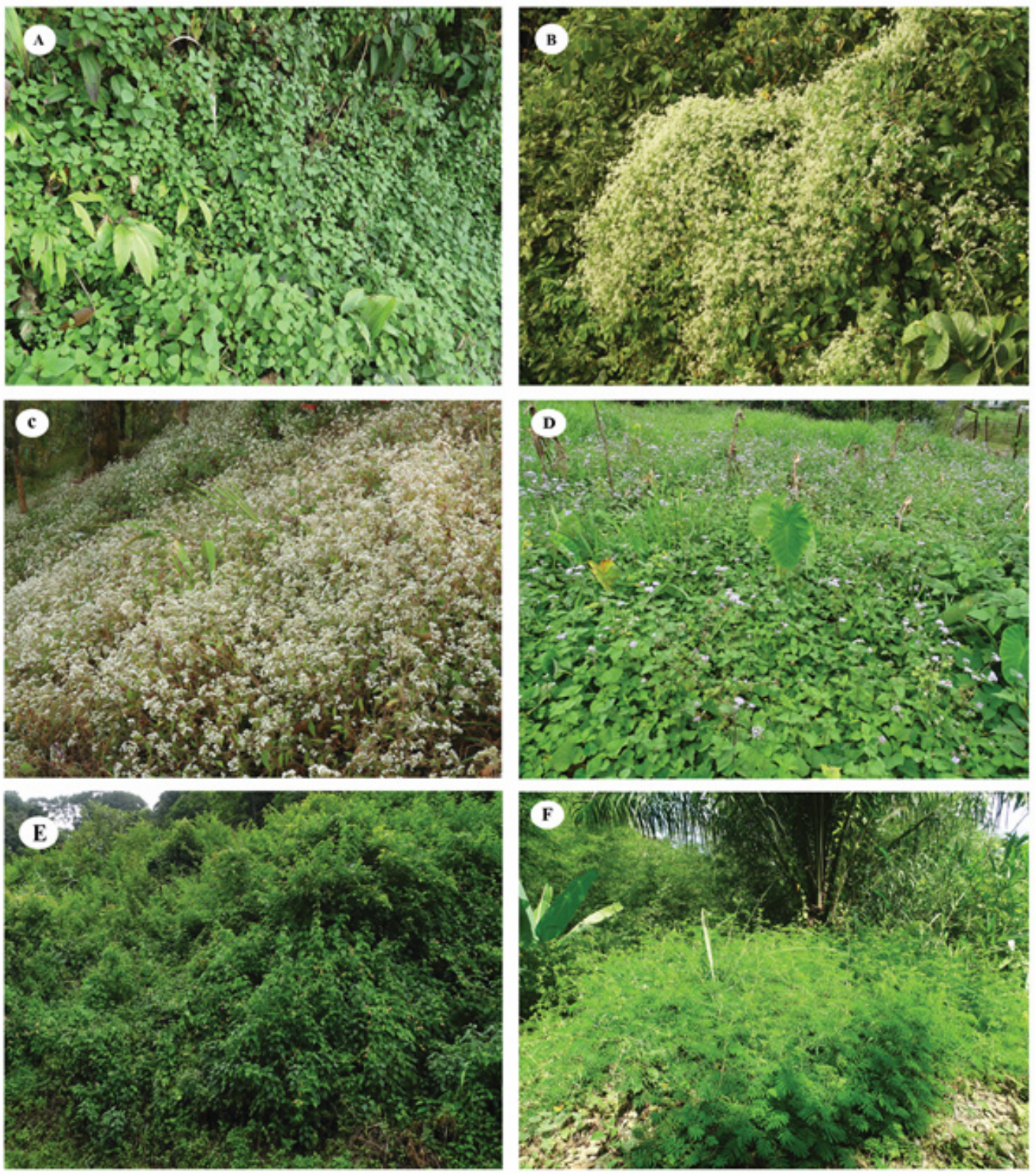

Figure 6. The invasive spread of (A) Ageratina adenophora (Spreng.) M.King \& H.Rob. (B) Mikania micrantha Kunth. (C) Ageratina riparia (Regel) R.M.King \& H.Rob. (D) Ageratum houstonianum Mill. (E) Lantana camara L. (F) Mimosa diplotricha Wright. in Mizoram, India

cairica, Crassocephalum crepidioides, Galinsoga parviflora are the most potential invasive species spreading aggressively between $500 \mathrm{~m}$ to 1800 $\mathrm{m}$ of elevation (Table 5). The most probable reasons for these rapid invasions and declining biodiversity may be attributed to allelopathic effect, fragile soil, a high influx of tourist, land clearance and the livestock-dependent lifestyle of local inhabitants of this region (Chen, Peng, $\& \mathrm{Ni}, 2009)$.
Some of the successful strategies which has been used to control invasive species include: (i) ecological restoration by allowing selected indigenous plant species with potential to outcompete invasive species to flourish, (ii) mechanical control in combination with cropcompetition method, and (iii) cut-root-stock method combined with introduction of native legumes and grasses (CBD, 2019), chemical control and biological control (Singh, 2017). 
Lantana camara was reported to be efficient in heavy metal as well as particulate pollution phytoremediation in Mizoram which shows promising use of invasive plants in pollution abatement phytotechnologies to assist in their sustainable management (Rai \& Singh, 2015). Education and awareness programmes developed by different agencies were essential which helped to restrict the spread of invasive species in the state. In this connection, during the study period, two awareness programmes were organized by the authors in collaboration with state Forest Department in Phawngpui national park and Mizoram University which had a great positive impact in the local stakeholders. Department of Environment, Forests and Climate Change, Government of Mizoram has taken up the task of developing a suitable framework to Control and Eradication of Forest Invasive Species in Mizoram (Singh et al., 2016).

\section{CONCLUSION}

Mizoram is a biodiversity-rich state and invasion of alien species is emerging as a significant concern for the conservation of native flora. Majority of the population are forest dwellers and mainly dependant on forest resources. Therefore, first-hand information on native flora and invasive flora is needed for formulating scientific management strategy for long-term sustainable utilization. Controlled practices of traditional slash-andburn cultivation, strict quarantine measures for importing of food crops and introduction of exotic plants are needed to be streamlined to strengthen a strategy for proper utilization, generate livelihood and wellbeing of the society. Regular awareness programmes may also to be conducted to appraise the local inhabitants about the impacts and control of invasive alien plants.

\section{ACKNOWLEDGEMENT}

The authors are grateful to Dr A.A. Mao, Director, Botanical Survey of India, Kolkata for encouragement and facility. The authors express their gratitude to the Department of Environment, Forest and Climate Change, Government of Mizoram for granting permission to survey and conduct this study. The authors are grateful to the Ministry of Environment, Forest and Climate Change, Government of India for financial support through the National Mission on Himalaya Studies (Project NMHS-2017/LG/01/475).

The authors express no conflict of interest.

\section{REFERENCES}

Batish, D. R., Kaur, S., Singh, H. P., \& Kohli, R. K. (2009). Role of root-mediated interactions in phytotoxic interference of Ageratum conyzoides with rice (Oryza sativa). Flora: Morphology, Distribution, Functional Ecology of Plants, 204(5), 388-395. doi://10.1016/j. flora.2008.05.003.

CBD (2019) Implementation of India's national Biodiversity action plan: An overview. Ministry of Environment, Forest and Climate Change, Government of India.

Chen, B. M., Peng, S. L., \& Ni, G. Y. (2009). Effects of the invasive plant Mikania micrantha H.B.K. on soil nitrogen availability through allelopathy in South China. Biological Invasions, 11(6), 1291-1299. doi://10.1007/ s10530-008-9336-9.

Curtis, J. T., \& McIntosh, R. P. (1950). The interrelations of certain analytic and synthetic phytosociological characters. Ecology, 31(3), 434-455. doi://10.2307/1931497.

Dogra, K. S., Kohli, R. K., Sood, S. K., \& Dobhal, P. K. (2009). Impact of Ageratum conyzoides L. on the diversity and composition of vegetation in the Shivalik hills of Himachal Pradesh (Northwestern Himalaya), India. International Journal of Biodiversity and Conservation, 1(4), 135-145. Retrieved from http://www. academicjournals.org/ijbc.

Downey, P. O., \& Richardson, D. M. (2016). Alien plant invasions and native plant extinctions: a six-threshold framework. AoB Plants, 8, plw047. doi://10.1093/aobpla/plw047.

FSI (2019). State of Forest Report. Ministry of Environment Forest and Climate Change, Dehradun. 
Higgins, S. I., \& Richardson, D. M. (2014). Invasive plants have broader physiological niches. Proceedings of the National Academy of Sciences of the United States of America, 111(29), 10610-10614. doi://10.1073/ pnas.1406075111.

Jaryan, V., Uniyal, S. K., Gupta, R. C., \& Singh, R. D. (2013). Alien flora of Indian Himalayan state of Himachal Pradesh. Environmental Monitoring and Assessment, 185(7), 6129-6153. doi://10.1007/s10661-012-3013-2.

Khuroo, A. A., Reshi, Z. A., Rashid, I., \& Dar, G. H. (2011). Towards an integrated research framework and policy agenda on biological invasions in the developing world: A case-study of India. Environmental Research, 111(7), 9991006. doi://10.1016/j.envres.2011.02.011.

Kohli, R. K., Batish, D. R., Singh, H. P., \& Dogra, K. S. (2006). Status, invasiveness and environmental threats of three tropical American invasive weeds (Parthenium bysterophorus L., Ageratum conyzoides L., Lantana camara L.) in India. Biological Invasions, 8(7), 1501-1510. doi://10.1007/s10530-005-58421.

Misra, R. (1968). Ecology Work Book. Calcutta: Oxford and IBH Publishing Co. (p. 224).

Rai, P. K., \& Singh, M. M. (2015). Lantana camara invasion in urban forests of an Indo-Burma hotspot region and its ecosustainable management implication through biomonitoring of particulate matter. Journal of Asia-Pacific Biodiversity, 8(4), 375-381. doi://10.1016/j.japb.2015.09.003.

Raizada, P., Sharma, G. P., \& Raghubanshi, A. S. (2008). Ingress of lantana in dry tropical forest fragments: Edge and shade effects. Current Science, 94(2), 180-182.

Reddy, C. S. (2008). Catalogue of invasive alien flora of India. Life Science Journal, 5(2), 84-89.
Rejmánek, M., \& Richardson, D. M. (2013). Trees and shrubs as invasive alien species - 2013 update of the global database. Diversity and Distributions, 19(8), 1093-1094. doi://10.1111/ddi.12075.

Rumlerová, Z., Vilà, M., Pergl, J., Nentwig, W., \& Pyšek, P. (2016). Scoring environmental and socioeconomic impacts of alien plants invasive in Europe. Biological Invasions, 18(12), 3697-3711. doi://10.1007/s10530-016-12592.

Sekar, K. C., Manikandan, R., \& Srivastava, S. K. (2012). Invasive alien plants of uttarakhand himalaya. In Proceedings of the National Academy of Sciences India Section B - Biological Sciences (Vol. 82, pp. 375-383). doi://10.1007/s40011-0120040-2.

Shankar, U., Yadav, A. S., Rai, J. P. N., \& Tripathi, R. S. (2011). Status of alien plant invasions in the north-eastern region of India. In Invasive Alien Plants: An Ecological Appraisal for the Indian Subcontinent (pp. 174-188). CABI Publishing. doi://10.1079/9781845939076.0174.

Simberloff, D., Parker, I. M., \& Windle, P. N. (2005). Introduced species policy, management, and future research needs. Frontiers in Ecology and the Environment. Ecological Society of America. doi://10.2307/3868440.

Singh, B. (2017). Study of controlling methods of invasive species in India. International Journal of Recent Research Aspects, 4(3), 10-16.

Singh, O. P., De, S.K. \& Cajee, L.(2016).State of environment report of Mizoram. Department of Environment, Forests and Climate Change, Government of Mizoram.

UN (2014). Global biodiversity outlook. secretariat of the convention on biological diversity (Vol. 25, p. 94). doi://10.2143/KAR.25.0.504988. 
Appenidix 1.

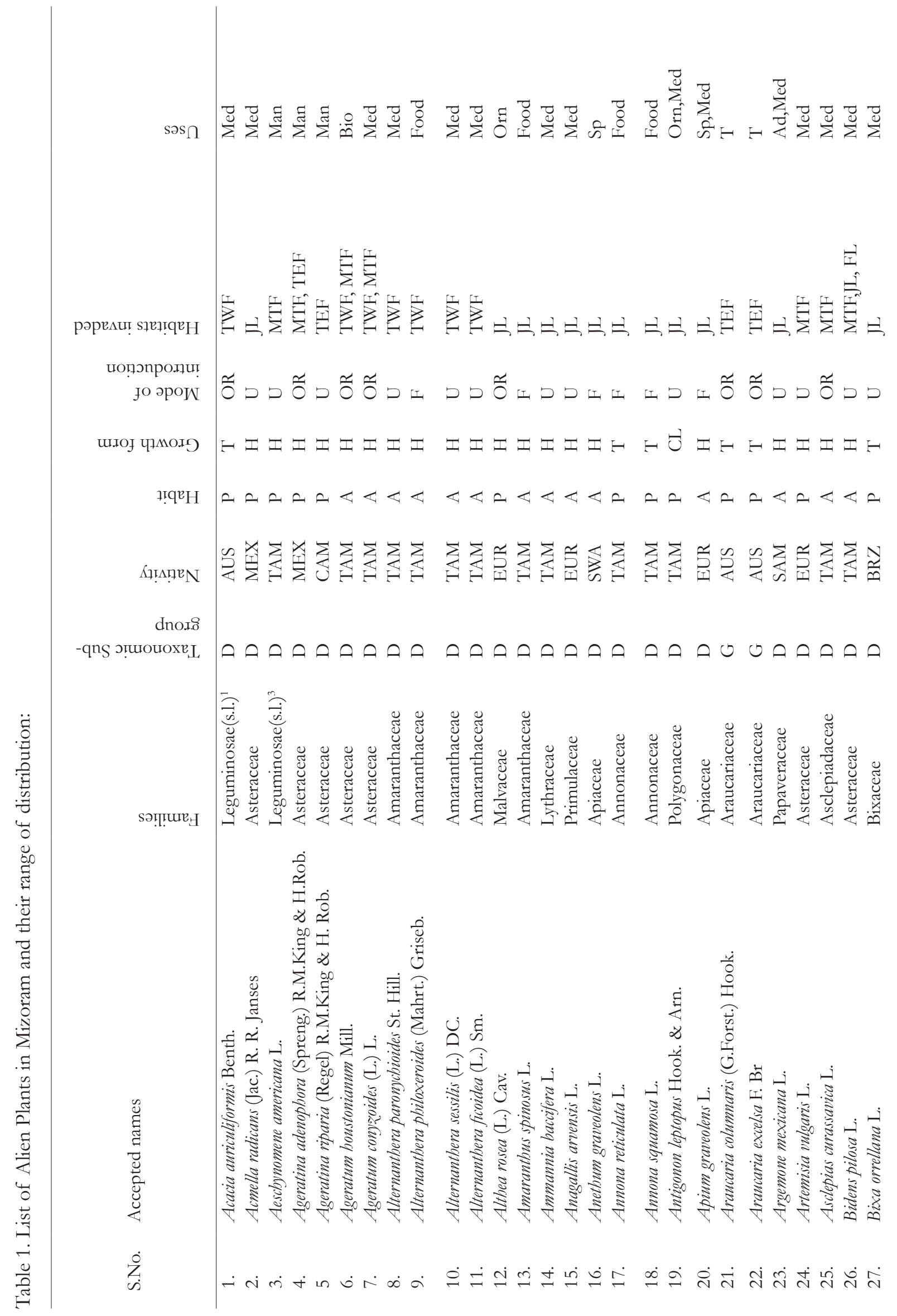




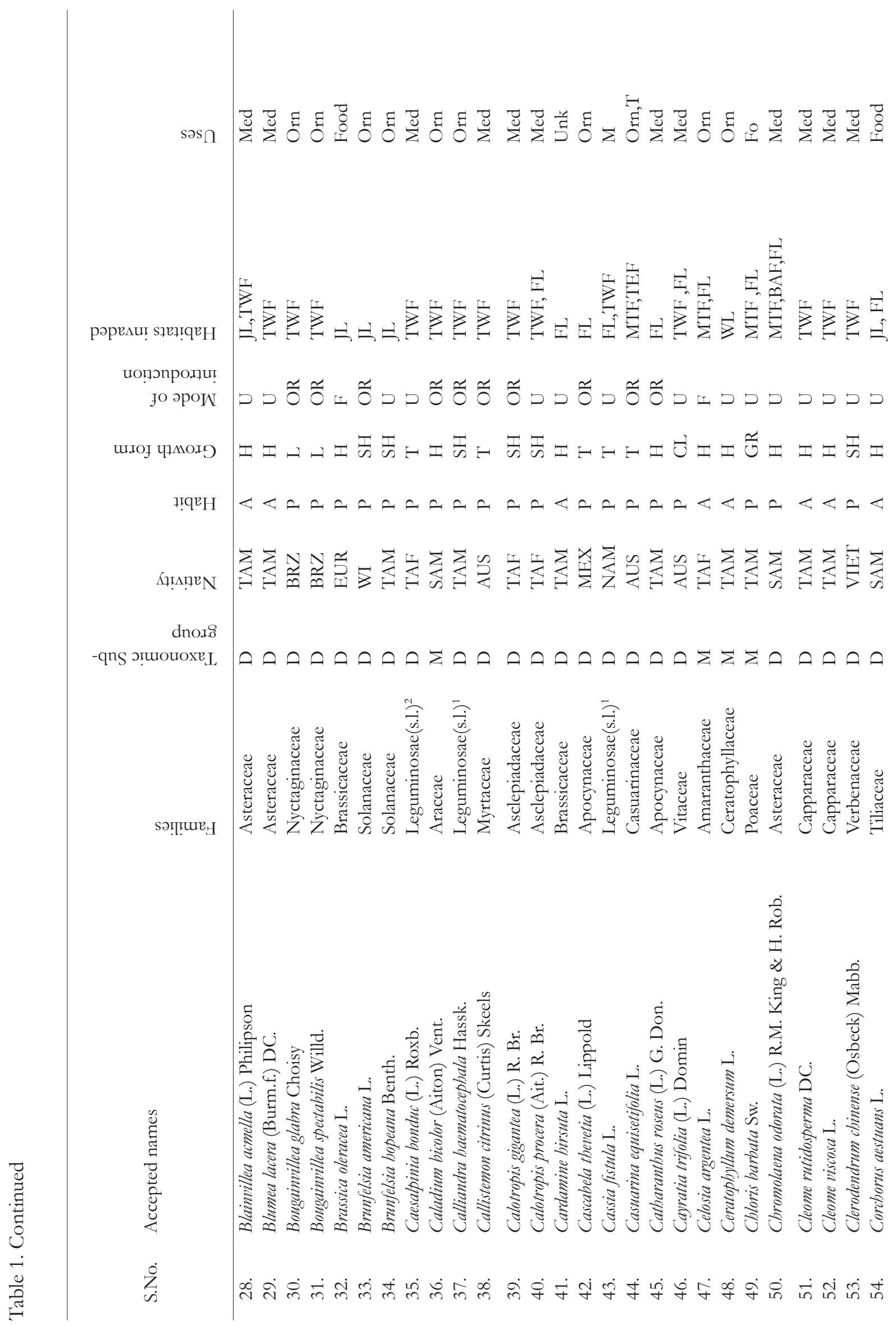




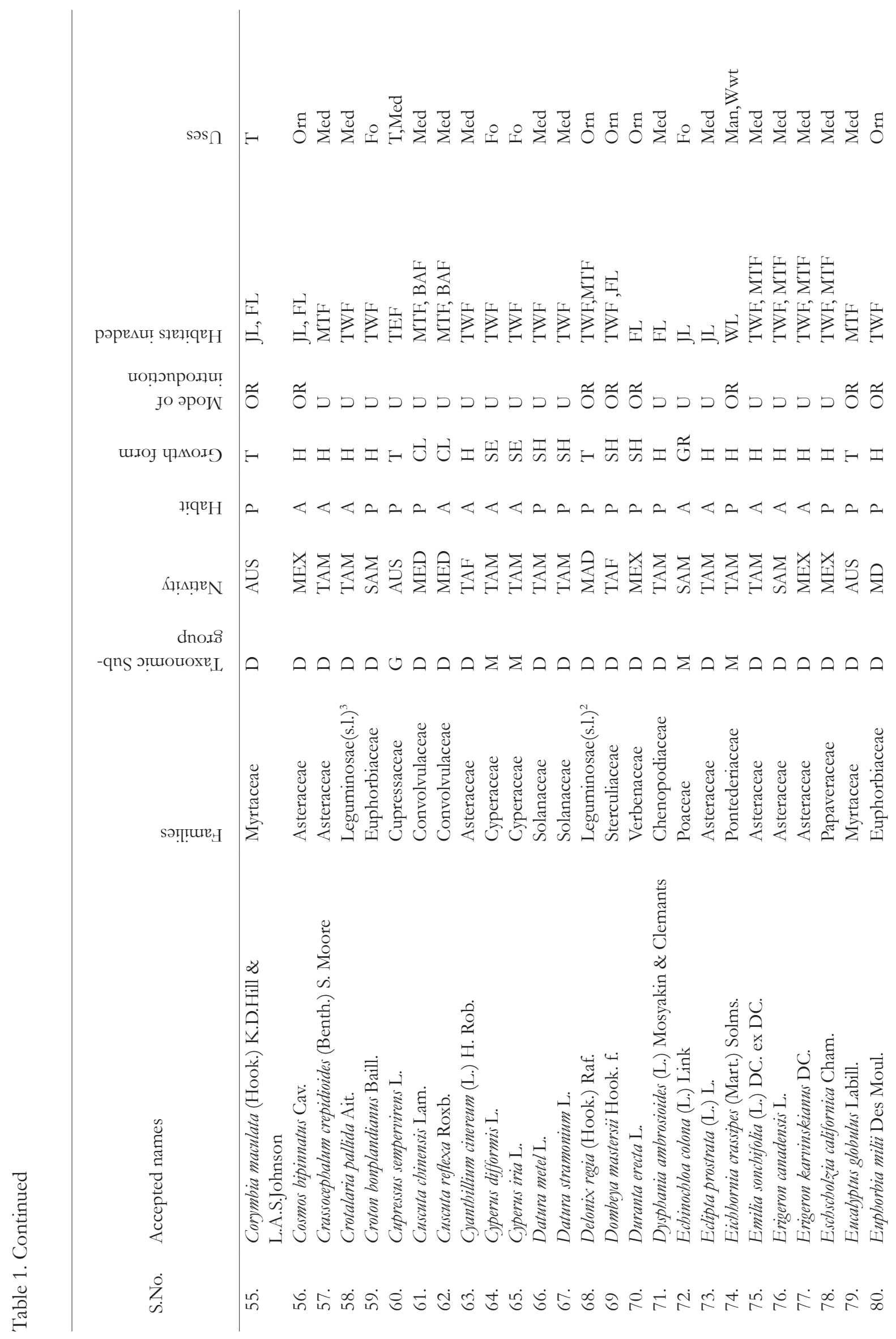




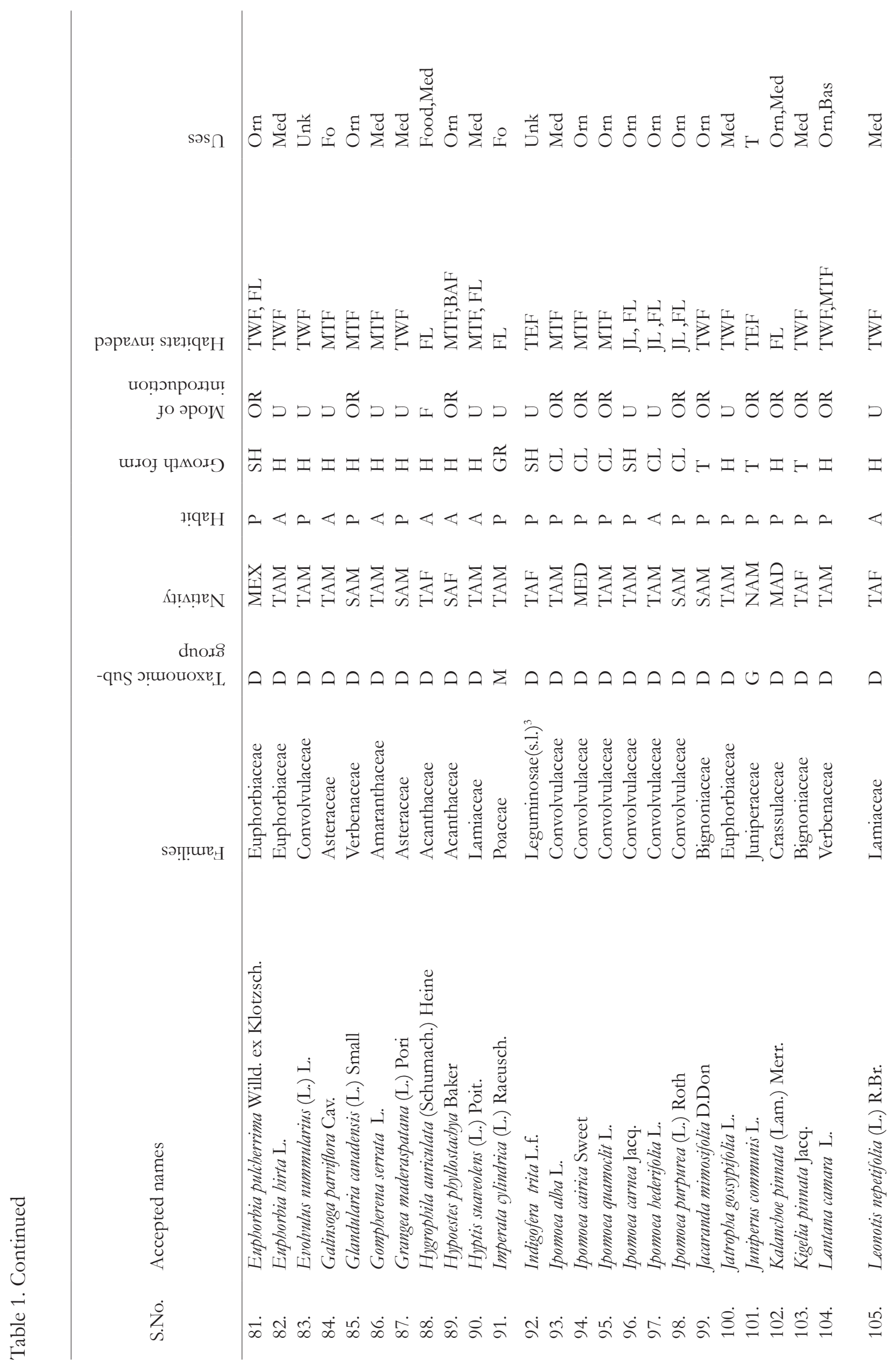




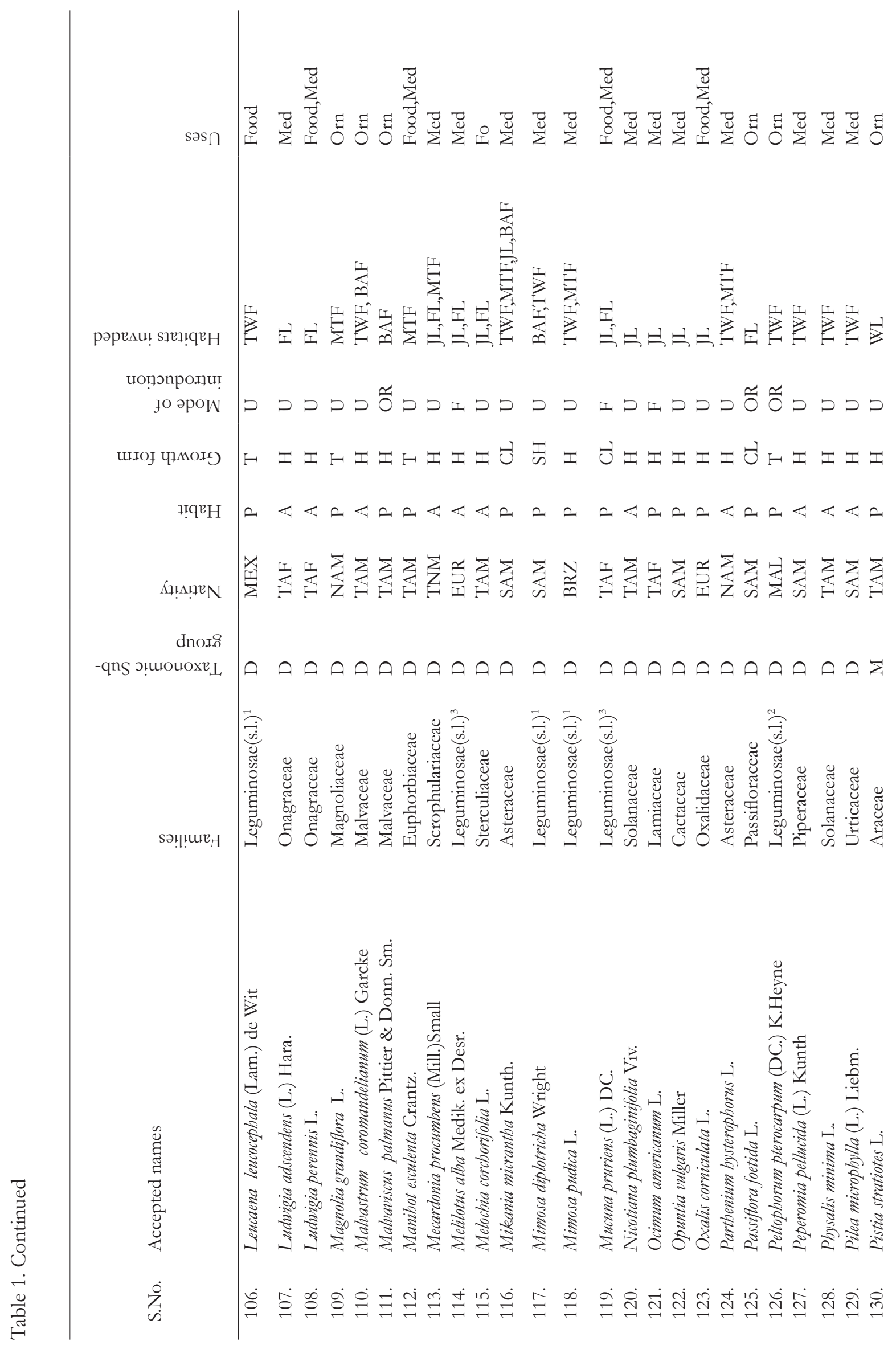




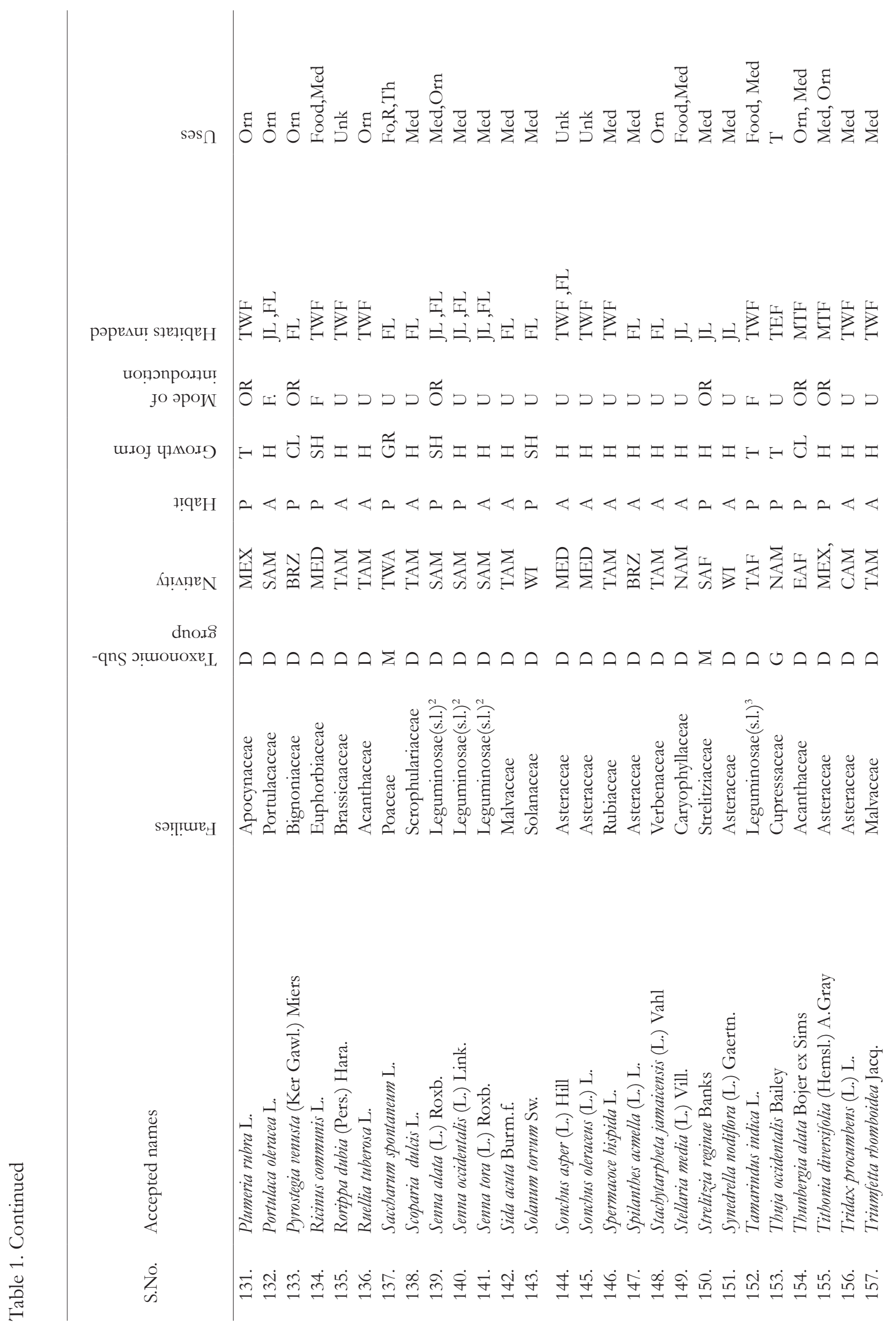




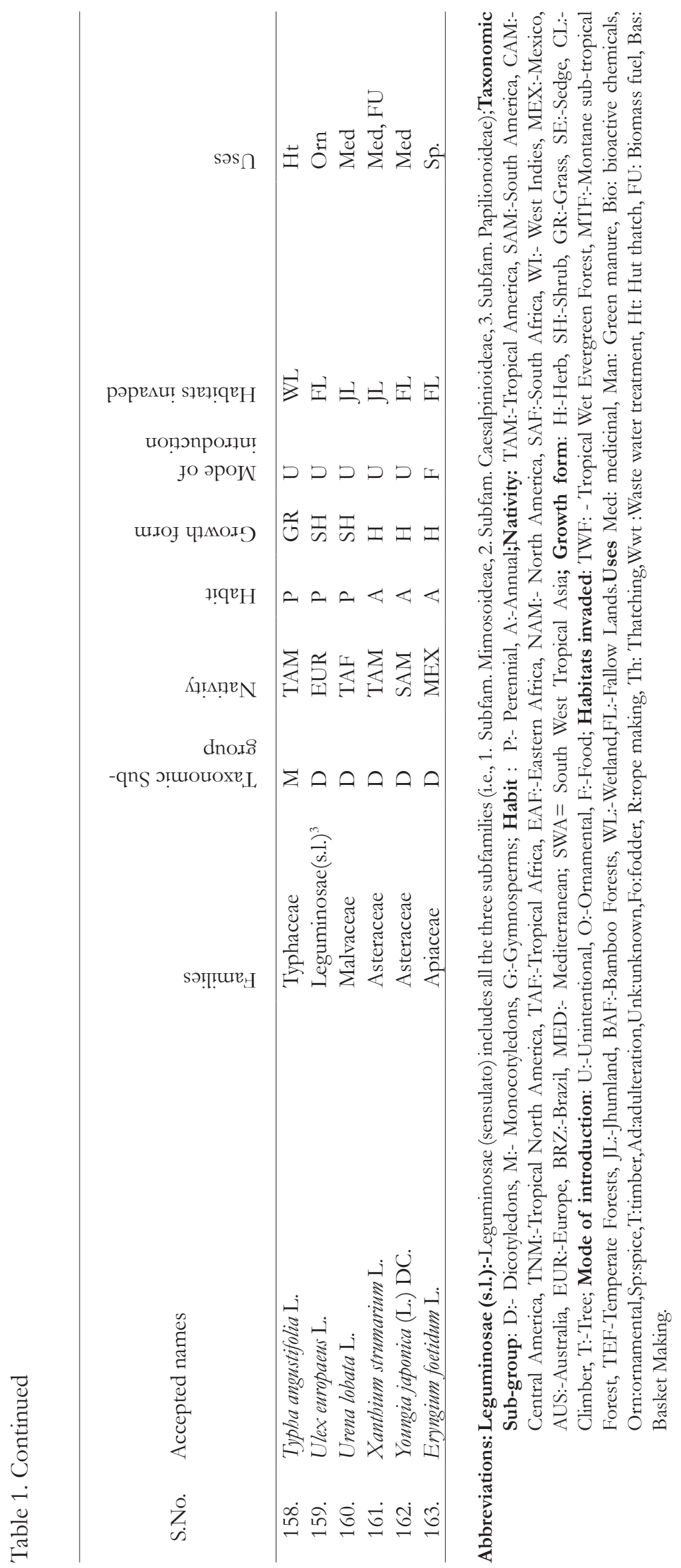

